Available online http://lumenpublishing.com/journals/index.php/jls

e-ISSN: 2067-8509; ISSN-L: 1841-6195

\title{
Jurnalul de Studii Juridice
}

Year XII, No. 1-2, June 2017, pp. 99-104

BOOK REVIEW: "FAMILIA ROMÂNEASCĂ - EVOLUȚIE SOCIALĂ

ŞI PROVOCĂRI CONTEMPORANE” ("THE ROMANIAN FAMILY - SOCIAL EVOLUTION AND CONTEMPORARY CHALLENGES"), AUTHOR: LECTURER PHD IULIAN APOSTU, BUCURESTTI, ROMÂNIA, TRITONIC, PƯBLISHING HOUSE

\section{Nadia-Cerasela ANITEI}

\section{DOI: https://doi.org/10.18662/jls/9}

Covered in: CEEOL, CrossRef, CrossCheck, Index Copernicus, Ideas RePeC, EconPapers, Socionet 


\title{
Book Review: "Familia Românească - Evoluție Socială Și Provocări Contemporane" ("The Romanian Family - Social Evolution And Contemporary Challenges'), Authors: Lecturer Phd Iulian Apostu, București, România, Tritonic, Publishing House
}

Nadia-Cerasela ANITEI ${ }^{1}$

\begin{abstract}
:
Divided into four chapters, the book is a blueprint for the conjugal Romanian space, from its classic - traditional structure and to new trends that come to redefine the relationships between the partners of the couple.

From another cultural perspective, traditionality seems to be strongly supported by religion, in itself, these environments involve hierarchical structures that are advantageous to men. Thus, over the general elements of functionality, cultural patterns tend to orient partners towards certain manifestations in the life of the couple. In our case, the Christian family receives a specific set of theological values, with its advantages or restrictions, therefore all the conjugal functionality receives influences in terms of solidarity, socialization and particularly, sexuality.
\end{abstract}

\section{Keywords:}

The Christian family, Romanian family marital, relationships in the family, Romanian marriage.

The author identifies the social intersection of traditionalism with modernity and, at the same time, the moment of a value-based transition, still unfinished for the Romanian marital space. Thus, as the author states, often the reluctance to the new, primarily specific to the man due to the loss of certain values of status, tends to slow down the process of modernizing the role behavior. In the current social space, arguing the superiority of the masculine status is difficult to justify rationally, reason for which the tendency of the social argument based on social stereotypes becomes in itself a strategy.

With their alleged generated social "legitimacy" that are widely known and least contested, the social stereotypes are often used as argument: "Who needs to cook in the family? A: The woman!; Who is the best chef? A: The man!". So adapting to equal conjugal role is atypical - men assume status values, but not the related roles. We often have a modernity of statements

${ }^{1} \mathrm{PhD}$ Univ. Prof, Faculty of Law, Social and Political Sciences, Dunărea de Jos University, Galați, Romania, e-mail: nadia.anitei@ugal.ro; ncerasela@yahoo.com

Anitei, N-C. (2017). Book Review: Familia Româneasca - E9volutie Sociala si Provocari Contemporane (The Romanian Family - Social Evolution And Contemporary Challenges), Author: Lecturer Phd Iulian Apostu, Bucuresti, Romania, Tritonic, Publishing House. Jurnalul de Studii Juridice, Year XII, No. 1-2, June 2017, 99-104. Doi: https://doi.org/10.18662/jls/9 
rather than concrete facts that define gender relations. This stage shows the assimilation of values at the ideological level, but the actual behavior still takes time until the "final update". The social moment of this intermediate stage of development of the Romanian conjugal structures is the current one. Researches conducted in the recent years in Romania shows still traditional influences in the hierarchy of gender, type of functionality, low levels of social contagion, particularly from their family $(47.4 \%$ of men and $33.7 \%$ of women consider the male is the head of the family, $52 \%$ of women assume daily shopping, over $80 \%$ of women take care of their household, etc. Source: Soroş, 2008)

From another cultural perspective, traditionality seems to be strongly supported by religion, in itself, these environments involve hierarchical structures that are advantageous to men. Thus, over the general elements of functionality, cultural patterns tend to orient partners towards certain manifestations in the life of the couple. In our case, the Christian family receives a specific set of theological values, with its advantages or restrictions, therefore all the conjugal functionality receives influences in terms of solidarity, socialization and particularly, sexuality.

The Christian family is considered to be that "normal" family, made up of husband, wife and children. We speak of a Christian family, as we relate ourselves to the teaching of the religious doctrine to Christianity, as "being the religion of love", and the family appears, therefore, a kingdom of love (Trifa, 2011, p.755). Theological writings define the Christian families as sub-communities, being a "Church in miniature", offering individuals testimony of their faith, and with other families, establishes the extent to which people believe they belong to the Church's laws (Iloaie, 2011, p.296).

The Christian perspective sees the family as a unity subjected to holy canons, so with a type of mechanical solidarity in which individuals must assume the moral norms prescribed by Christianity.

And also from a religious perspective, Muslim cultural challenges also come with conjugal clarifications that define a certain type of fusion between men and women. "From a religious point of view, Islamic identity is built on two aspects: the social actors and the institutions in that society. Taking into account these statements, we believe that "social actors must deconstruct themselves as subjects, in order to become individuals and members of an ethnic group or a nation's citizens." (Castells, 2001, p.16)

In the Islamic vision, the man is the woman's protector, because, physically and emotionally, Allah gave him more power. That is why women must remain subject to it. They are socialized in this culture from very young age, which makes it much easier to adopt this system of masculine domination. 
By 1917, Turkish reformer Mustafa Kemal Ataturk produced a sudden change. He was among the first leaders to change values and concepts, which until then kept the woman in a lower place, giving them equal rights with men. (Doğramac1, 2000, p.1)

He argued that women in this society have always struggled to fulfill their social obligations with their spouses, whether it was activities involving the sphere of agriculture or family support even financially, and more so, women were an indispensable component of the structure of the company in question.

According to the tradition, in the newly formed family, the wife must join her husband and live together, usually in her husband's father's house. Thus, the relationships in the family are consolidated, tradition is respected and is developed a principle of reciprocity on support that grandparents give to their grandchildren, and later the boy and his wife, transmit to the elders: "Nobody offers a lunch for nothing without taking into consideration reciprocity. "(Marilyn Booth Bahar Davary, Gualtieri Sarah, Elora Shehabuddin, 2009 p. 122). The woman who married was recognized as part of the husband's family only after giving birth. Sh was under the control of the mother of her husband, being a direct relationship of subordination. We so notice that it gradually reveals a new legal orientation, but the landmarks of the religious tradition still stimulate hierarchical behaviors in the marital conjugal relationships.

From a social point of view, women's activities, especially in small towns, are still limited. The most common activities are purchases or implications in religious encounters. Women are retiring from the labor market when they get married, "paid work being considered more appropriate for unmarried women, putting social pressure on married women." (Akpinar, 1998, p.30)

It should be noted that certain texts of the Qur'an don't expresses the same idea of gender equity such as the one declared by certain theologians. Appreciating the dogmatic dimension of polygamy, from a Muslim perspective, Islamic theology makes a social hierarchy of the sexes, the man being the superior of a family. "Men are superior to women, because God has given them priority over them, and because they are endowed with their goods." (IV , 38) and "women ... are for you a field, so go into the field as you will "(II, 223). The polygamous marriage is regulated by the Qur'an when it says that "if you are afraid that you will be unjust with the orphans, marry yourself with the women who look good to you: two, three or four. And if you are afraid you are not righteous, then marry yourself "(IV, 3). Thus, gender inequality trend is evident in the Qur'an but 
the specific cultural Muslim countries make this form of this disparity less visible.

Returning to the details of legal sociology regarding the Romanian marriage, the author highlights the new individualist tendencies in the New Civil Code.

Economic policy formulation before or during marriage shows a new type of marital attitude that betrays a reduction in the level of solidarity in favor of classic "cautious" mentality, oriented towards itself. If the previous marriage was centered on "us", today, its legislative provisions allow partners to focus more on themselves. Legislature creates the structure of the good personal relations prevailing postmodern common good family, the "I" becomes a priority in from of "We". Protecting personal property becomes "security strategy" of postmodern marriages, the "vulnerability" of the offer becomes more of a risk than a proof of trust for the "beloved partner".

Statistically considering Romanian family marital stability, the author notes that in terms of divorce, Romania is among the EU countries with the lowest divorce rate. Although divorce proceedings were relaxed gradually through 1993, then 2010 and 2013, however, the divorce rate has increased, as has happened in France, Germany, Belgium, etc. If not unitl 2013 that the divorce rate was hovering around the value of $1.5 \%$, in 2016 it dropped to $1.37 \%$, indicating that Romanian family remains stable, although the conditions for gaining access to legal separation were facilitated.

Furthermore, the rules on engagement, relaxation of divorce proceedings, patrimonial regimes are looking like new ways of promoting a new type of marriage in which each partner personally receives the legal security of his own assets, and at the same time the possibility to divorce under much simplified conditions.

Also, one of the dimension that the author assigns special attention to is the problem marital union. The author points out that the statistical data obtained from the 2002 Census show that the number of those who declared themselves to be in a consensual union is statistically significant, but the data do not seem to be relevant. According to Census 2002, in Romania were said to be 338136 marital couples, which means a total share of $3.9 \%$, with a higher distribution in rural areas $(4.6 \%)$ than in urban ones $(3.2 \%)$

The technical problem, visible in present social studies can be concretized in the fact that no research tool has made the difference between consensual union as an alternative to legitimate marriage and the consensual union mentality as a premarital state. So the existing statistical data is relative. The analysis of the 2002 Census data highlights the presence 
of cohabitation phenomenon with a substantial increase immediately after the highschool study period, around the age of 20 (from 7040 to 51407 persons) and a decrease in the frequency from the middle age to marriage (from 74407 persons in a consensual union to 67586 persons). However, the frequency of these data rather shows a "concubinage" as premarital status, than an alternative to marriage.

The author points out that it is not just the equalization of the consensual unions an act itself, which recognizes a fact, but a complex legal system with a wide variety of legal consequences, fiscal, economic, and social aspects of parenting.

In the first stages of legalization, the consensual union in its different forms was only a set of national challenges, the generalization of this phenomenon at the level of Europe led to a tendency of international adaptation of the legislative systems in such a way that the marital partnerships between the partners coming from different countries are now allowed. At the same time, an important part of the countries that have developed such systems of law sought to prevent tourism marriage, the first country that has provided legal recourse to avoid becoming "a new Las Vegas" is Denmark (Lund-Anderson, 1998 , p. 339).

In Romania, there were three legislative proposals to legalize the consensual union and none of them indicated their tax rights, property or regulations concerning the transmission of contracts, the possibility of adoption, etc.

One of the biggest dilemmas associated to the legalization of consensual union in Europe has been homoparentality. Although they have not anticipated it from the beginning, the existence of children in same-sex couples was impossible to keep under control. Today, almost all European legislation remains "vulnerable" to homoparentality. Initially, all European legislation on legalization of cohabitation prohibited the adoption and medical reproduction of homosexual couples, but no European legislation could prohibit adoption by a single person. Therefore, the strategic reaction of gay partners was to seek adoption as a single person. In this way, the quality of parenthood legally belonged to one partner but the relationship with the children was developed by both partners. The beginnings of these procedures have sparked harsh reactions from the heterosexual side, which have consequently had effects - encouraging gay communities to demand the right for adoption.

Another issue that generated homoparentalitate phenomenon was a rare category of partners, who seeking their sexual identity had, in the early stages of conjugality, relations with women resulting children. The moral dilemma of such cases has become so much bigger. The society which 
requires the removal of the child from the gay environemtn, action which would be equivalent to separating the child from its parent, which led to a different set of social controversies.

Romania does not seem to want the legalization of concubinage too much, and even less, the legalization of relations between two same-sex partners. According to EOS Gallupe Europe, 2003, Romania is in the category of countries with the highest legacy of legalizing same-sex relationships. Yet, beyond a type of intolerance that derives from a theological or general social culture, the legalization of the consensual union also concerns the issue of resources.

Today, the Romanian family is still in the transition towards modernity, although at a less representative level, Romania also knows postmodern marital structures or couples of concubines who, although developing family-specific marital structures, are not legally married. Overall, assimilating the conjugal modernity is not a fixed process, covered by all individuals at the same pace or in the same way. Being in different stages of development, individuals build relationships through which to validate their values they believe in, basing marital cohabitation different variants depending on modernity or postmodernity. The Romanian family, therefore, remains statistically stable, but not always happy due to the difference in value, asymmetrically assimilated by each partner. With many traditional influences, grievances are neglected or tolerated, with a large group of partners preferring to accept this compromise. So, marital stability is statistically satisfying, but it is not always happy. Law 396/2006 provided young couples with social benefits of $200 €$ to the first-married, and the greatest impact of this law was observed in an increased number of marriages in the 18-24 age group and especially in poor communities. The law only produced effects in the first year of application. It is interesting to note that the $€ 200$ resource could influence the decision of getting married. This shows once again the fragility of couples in this category, that can be influenced up to the level of the authentication of a relationship based on benefits that are only effective in the short term.

Anitei, N-C. (2017). Book Review: Familia Româneasca - 104 Evolutie Sociala si Provocari Contemporane (The Romanian Family - Social Evolution And Contemporary Challenges), Author: Lecturer Phd Iulian Apostu, Bucuresti, Romania, Tritonic, Publishing House. Jurnalul de Studii Juridice, Year XII, No. 1-2, June 2017, 99-104. Doi: https://doi.org/10.18662/jls/9 